\title{
RESEARCH \& DEVELOPMENT NEEDS OF PALMYRAH BASED PRODUCT PROCESSING INDUSTRY
}

\author{
K. SIVAGANESHAN \\ Palmyrah Development Board, 244, Galle Road, Colombo 04.
}

The female palmyrah palms have a potential of producing 15,000 to 20,000 metric tons of palmyrah fruit pulp annually. The pulp contains as its major components (on a fresh weight basis), moisture $76 \%$, sugar $1.5 \%$, pectin $6.7 \%$. The sugar comprises of sucrose $6.6 \%$, glucose $3.5 \%$, fructose $3.4 \%$ and unidentified sugar $1.5 \%{ }^{1}$

This fruit pulp has been used traditionally either in the dried form "Pinattu" or a fresh pulp mixed with rice flour or wheat flour and made into oil cakes "panankaipaniyaram" for decades. More recently the Palmyrah Development Board in an effort to popularize fruit pulp has converted it to a number of edible products such as fruit drinks, cordials, jams, concentrated pulp, fruit bread, chocolates, pulp mellows and pulp delight. The fruit pulp has a characteristic bitterness which is a drawback in efforts to popularize the product or even export it.

Hence, it is important to debitter the fruit pulp. Leaching, adsorption, ion exchange, masking and dilution had little effect on debittering. The technique of bio-conversion for debittering with Nariginase has been successful. ${ }^{1}$

Although debittering has been a success technically, it still had problems, Firstly nothing is known about the toxicity of the product of debittering. Animal feeding studies will be needed to test for physiological effects (if any) of the non-bitter products of Naringinase. ${ }^{1}$ It is hoped that with the rapid strides made in the field of Biotechnology these costs will decline in the next few years.

\section{Research on Starch}

The palmyrah tuber is a rich source of starch which has an existing potential of $\mathbf{3 0 0 0}$ metric tons of tuber flour annually. ${ }^{2}$ The tuber is potentially comparable to other starchy stables like rice and wheat, maize, potato, cassava as a source of flour. It has however a serious drawback in the presence of a bitter after taste. Keeping this factor in mind it appears logical to convert the flour to a more purified product namely starch. Preparation of starch would also open a new avenue namely the production of nonedible industrial products from starch. Further studies could be carried out for the production of malt powder, liquid glucose, and high fructose syrup from tuber flour.

\section{Research on Sap Products}

Palmyrah sap, fermented (toddy) as well as unfermented (sweet toddy) are the major products of economic value from the palm. Total sap produced per year is approx. 80 
million bottles ${ }^{3}$. The sale value from sugar and alcohol as by products is in the region of Rs 680 million. If the sap is used exclusively for alcohol production then the expected return would be Rs.13,000 million per annum.

High yield of alcohol could be obtained if the sweet toddy is fermented using special strains of yeast using the technology of cell recyling. ${ }^{4}$ By using immobilized invertase and glucose isomerase the sucrose in the sweet toddy could be converted to high fuctose syrup, which is widely used in soft drinks like Coca Cola, Sprite etc. ${ }^{5}$

\section{Table 1: Macro Constituents of Palmyrah Fruit Pulp. ${ }^{6}$}

\begin{tabular}{lll}
\hline Moisture & $76 \%$ & \\
Organic matter & $16-61 \%$ & Fresh weight \\
Minerals & $4.3 \%$ & Fresh weight \\
Sugars & $14-16 \%$ & Fresh weight \\
Crude Protein & $2.76 \%$ & Dry weight \\
Free Amino acid & $1.52 \%$ & Dry weight \\
Fibre & $1.5 \%$ & Dry weight \\
Pectin & $20.8 \%$ & Dry weight \\
Lipids & $1.02 \%$ & Dry weight \\
\hline
\end{tabular}

Table 2: Macro Constituent of Sweet Toddy ${ }^{\text {? }}$

\begin{tabular}{lc}
\hline Total Sugar & $10.93 \%(\mathrm{~W} / \mathrm{V})$ \\
Protein & $0.35 \%(\mathrm{~W} / \mathrm{V})$ \\
Reducing sugar & $0.96 \%(\mathrm{~W} / \mathrm{V})$ \\
Phosphorus & $0.14 \%(\mathrm{~W} / \mathrm{V})$ \\
Vitamin C & $13.25 \mathrm{mg} / 100 \mathrm{ml}$ \\
Vitamin B & $3.91 . \mathrm{U}$. \\
Minerals & $0.54 \%$ \\
\hline
\end{tabular}

\section{References}

1. Jansz E.R. \& Theivendirarajah K. (1992). Exploitation of palmyrah fruit pulp for agro-industry-Seminar on new dewelopments in the exploitation of palmyrah in Sri Lanka.

2. Jansz E.R., Karunatillake N. \& Theivendirarajah K. (1992). Extraction and exploitation of palmyrah tuber starch for agro-Industry - Seminar on new development in the exploitation of palmyrah in Sri Lanka.

3. Thirulinganathan T. (1992). Palmyrah based production - an economic overview Seminar on new development in the exploitation of palmyrah in Sri Lanka. 
4. Seevaratnam S., Hjorleifsdottir S., Holsf H. \& Mattiassan B. (1990). Effects of complete cell receding on product formation by Lactobacillus Casirhomanosus in continuous culture. Current Microbiology 20: 287-292.

5. Balasubramaniam K. (1983). Immobilization of ligands and their application. Proceedings of the Institute of Chemistry (Ceylon) 12: 7.

6. Jeyaratnam M. (1986). The chemistry and biochemistry of palmyrah products. M.Phil Thesis, University of Jaffna.

7. Paulas D. \& Muthukrishnan C.R. (1983). Products from palmyrah palm Workshop on Palmyrah, Jaffna. 